\title{
Community policing in the Netherlands: A continuously changing constant
}

\author{
Arie van Sluis \\ Lex Cachet \\ Peter van Os \\ Ruth Prins \\ Peter Marks
}

December 20, 2010

\section{Introduction}

1977 was an important year for the Dutch police as it was then that a seminal strategy document called 'A Changing Police was published that would set the course for the next three decades. The writers of the report felt that for the police to bridge the growing gap between them and the society they serve, they would have to be innovative, and think outside of their usual security paradigms. They found their solution in community policing and the strategy document laid out the framework for Community Policing (COP) in the Netherlands. This document was widely considered a milestone in the development of Dutch policing (see Cachet et al. 1998).

However, by 2005, the Dutch Board of Chief Commissioners felt it necessary to publish a new strategy document to once again map out the future of Dutch Policing. After nearly three decades, the Dutch police was again in need of a shared philosophy that would serve as a foundation for their mandate. This new document was titled 'The Police in Evolution' (PIE) but it stayed true to the values of COP by once again focusing on the local community and stressing community policing.

In this paper we explore the establishment and development of Dutch COP. We look at several distinct phases in the long term development of Dutch COP, and examine the factors that explain the shifts that have taken place in the way Dutch COP is carried out. We ask also about the prospects of Dutch COP in the future.

The paper will consist of four sections. In the first Section, we examine the historical roots and the development of Dutch COP since its inception in 1977. In Section 2, we look at the current state of affairs for COP in the Netherlands. In the third section, we put forward several explanations for the significant shifts that have taken place over the course of the COP's 30-year history. In the fourth section, we discuss the prospects for Dutch COP in the coming years. Section 5 presents our conclusions.

\section{Distinct Phases in the Development of Dutch COP}

The concept of Dutch COP is neither clearly defined nor static. Nonetheless, we follow from Terpstra $(2010,217)$ in assuming that the strategy has five central ambitions: 1 . reducing the rift between the Dutch police and citizens; 2 . maintaining a keen focus on a range of problems in the neighbourhood; 3 . taking a preventive approach and a proactive work style in addition to a reactive one; 4 co-operating with other agencies; and 5. encouraging citizen involvement. 
While the main aims of COP have not changed over the years, the shape and feel of the COP effort have varied significantly during different phases of its development.

As we will show in subsequent sections, there seems to have been a constant balancing and adjusting of three basic orientations that are simultaneously fundamental to modern policing.

\section{State, Community and Profession}

The first of this is the traditional view of the police as the strong arm of government. Under this orientation, the police are state-centered and their work is geared towards the tasks associated with state control, including repression (Punch, 2010, p. 203). The focus under this orientation is not only on crime control, but also on the maintenance of order on a large scale and the management and prevention of large scale incidents. Key words associated with this orientation are the state, vigilance, vigor, repression, centralization, uniformity and 'hard policing'.

The second orientation impacting the shape and form of Dutch COP is that of the police as a service to the (local) community. This orientation is usually associated with community oriented policing. Key words associated with this second orientation are the local community, responding to local need and demands, citizens involvement, legitimacy, tailor made solutions, fragmentation, 'soft policing', and prevention.

While the state centered perspective focuses on hard policing or the grave matter of catching crooks, the service orientation uses "soft policing" which refers to the broader social tasks within the community.

While the two orientations appear seemingly opposite, both exert significant pressures on the form and function of the Dutch police force. The police are viewed both as the strong arm of power, belonging to a strong, central, government, and as the protectors of the rights and freedoms of ordinary citizens in the community. The third orientation is that of the police as a profession. The PIE document from 2005 states that while the police are subordinate to the police authorities, they have the professional authority to claim an autonomous role in the formulation and implementation of police policy. Key words under this perspective are the police organization, competence, professional autonomy, discretion and police education. As stated above, the three perspectives exist simultaneously, with each coming to the fore at different times depending on the political and social climate. An exclusively state oriented and state controlled police cannot meet the requirements of a democratic constitutional state, nor does it ensure that policing is done according to high professional standards. At the same time, a police force geared exclusively to local needs and wants of citizens results in a powerless police that lacks the authority and independence to act in conflicts between societal groups. Similarly, neglecting the third orientation of the police as a professional body can lead to poor training, incompetence, and policies that are difficult to implement, while overly stressing the police's status as a professional group may lead to the undervaluing of their democratic accountability and reduce the focus on local needs. This may then increase problems of legitimacy.

Below, we identify five successive phases in the evolution of Dutch COP based on shifts in its position with regard to these three basic orientations.

\section{Phase 1: Fighting for existence (1970s and early 1980s)}

The first major shift in the direction of Dutch policing after the Second World War arose in the 1970s. It was at this time that the traditional (professional) model of 
policing was viciously attacked for being incapable of dealing with the more complex and dynamic problems faced by Dutch society.

Before 1977, the role of a police officer was primarily to enforce the law and to make arrests. Police discretion was neither acknowledged nor accepted and tasks were simplified and standardized by the use of standard operation procedures. Specialised units were created to handle more complicated problems. There was a degree of concern about the professionalism of the police, but this progressed largely through the use of technology. For example, squad cars replaced surveillance on foot and citizens were seen merely as recipients of professional police services (van Sluis, 2002). The police in this era acted clearly as the strong arm of government. This state centered force was a distant, highly centralized and strongly technocratic form of policing that had its roots in an earlier time when society had much confidence in technology and social engineering and progress.

But the 1960s left the Dutch police with gigantic losses in their legitimacy. The rigid and repressive style adopted during the student protests of the period resulted in particularly bitter criticism of the police. The Dutch police found it necessary to reintegrate themselves into the society and regain the trust of their citizens.

In looking for ways to re-establish their mandate, the Dutch police found inspiring examples from the USA.

It took the better part of the decade, but the new philosophy was crystallized in the 1977 strategy document 'A Changing Police'. The document clearly stipulated that police work should be done by well-educated policemen oriented toward the good of the community. Such policemen should work both individually and in teams under the framework of a horizontal, decentralised organisation.

After 1977, Dutch police started experimenting with COP. The first community police officer was a beat constable working in a limited area with the broadly defined task of keeping the neighbourhood safe and quiet and restoring contact with citizens (Punch et al., 2002). Not surprisingly, the first beat officers met with a lot of criticism from their colleagues for not being "real policemen". At the same time, they were criticized by the public for being too soft, for always being alone and were accused of lacking any authority. This initial criticism resulted in the creation of neighbourhood teams that aimed for both external integration between the police and the public and integral integration between departments of the police organization.

\section{Phase 2: COP as the new orthodoxy (late 1980s and early 1990s)}

Despite the introduction of COP in 1977, by the early 1980s, most police forces had failed to implement neighbourhood teams. Even when it was implemented, things were not always smooth sailing. For example, the city of Delft had a medium-sized force that was designated a COP pioneer in 1980. However, their pilot program ended prematurely because both the detectives and the uniformed officers felt threatened and opposed the intended changes. Further, the chief of police himself showed himself to be ambivalent in his support of the pilot project, and the public prosecutor openly expressed his doubts about the quality of crime control under this new model (van Os, unpublished paper).

While their experiment was doomed to failure because of the poor support of key figures, other forces had greater success. The municipal police of Haarlem successfully adopted and implemented neighbourhood teams in three areas. And once the municipal police of Amsterdam (which is the leading police force in the Netherlands) adopted COP, many other police forces followed soon after. By the beginning of the 1990s, nearly all forces in the Netherlands had adopted teams 
based on 'A Changing Police'. COP become the standard way of delivering basic policing and became the new orthodoxy of policing (Punch et al., 2007).

\section{Phase 3: Competing perspectives on policing (1990s and early $21^{\text {st }}$ century)}

Just as COP became the dominant policing model, the social and international environment changed. While the shift toward the COP model was triggered primarily by concerns over the loss of police legitimacy, its implementation coincided with major changes in the social climate in the Netherlands.

New developments took place in the field of public order in the late 1980s, specifically that the squatter movement grew significantly and presented a new challenged to the police, as did football hooliganism and a vast increase in the number of petty crimes. In the 1990s, the Netherlands also experienced the emergence of more professionally organized and more international forms of crime, all of which served to undermined the predominance of the COP. It became clear that while a COP perspective was important, the police had to be able to serve their old role as the strong arm of government to an extent if they were to achieve their primary goals of crime control and public order maintenance. These developments stimulated the growth of a new degree of professionalism in law enforcement and the re-establishment of specialized units to deal with complex new forms of crime, first at the regional level and later on at the national level.

As a result of these pressures, by the 1990s, COP had gradually lost its status as the dominant policing model and as a remedy for all diseases. Zero tolerance policy became a feature of Dutch policing in the big cities, as did broken windows policing and hotspot policing. Just as COP itself was inspired by the US experience, the move toward these more hardline approaches was also inspired by American and British experiences of criminal activity. The shift in focus occurred also against the backdrop of a growing sense that the Dutch tradition of tolerance had gone too far and police had to focus on catching criminals again (Das et al., 2002; Punch et al., 2005).

\section{Phase 4: COP as area bound policing (after the 1993 Police Act)}

Just as it appeared that COP was beginning to take a back seat to the new initiatives, it was unexpectedly revived in 1993 when a new Police Act came into being. The act merged the 148 Dutch municipal police forces and the State Police into 25 regional police forces. This regionalization and the up scaling of the police was aimed at improving police performance, especially in crime control, but shortly after regionalization, area-bound policing was introduced in almost all regions (Beumer, 1997). New community officers were introduced who unlike the beat constables, were not ordinary cops. These new community officers were made responsible for organizing security in their area in a much wider and more permanent sense. They were called area managers or neighborhood directors and they were supported by their colleagues in specialized departments (Punch et. al, 2007).

During this period, the COP movement was characterized by the need to restore the balance between centralizing tendencies (as seen by a drastic increase in scale of police forces) and decentralizing tendencies (specifically the wish to strengthen the bonds between the police and local communities).

The shape of COP in the 1990s reflects important shifts in local safety policy in the Netherlands and the ever changing role of the police. From the early 1990s on, the 
central government puts a lot of effort into stimulating local authorities to develop their own local safety policies.

As a consequence of this, the police found themselves having to rethink their core tasks and role in the chain of collaboration with other parties (De Kimpe and Cachet, 2008). Gradually, the role of the police in local safety programs became less and less dominant as the rise of independent local safety plans and the concomitant introduction of a variety of local supervisors gave the police an opportunity to dispose of certain policing tasks that they considered improper as well.

In summary, this period was defined by the movement away from the earlier overwhelming emphasis on the profession and on scale enlargement and a reprioritization of the community.

\section{Phase 5: New realism, pragmatism in policing (2005 ...)}

The early $21^{\text {st }}$ century saw more changes in the shape of Dutch COP. The new vision of COP was articulated in the strategy document called the 'Police in Evolution' (PIE). This document arose with the backdrop of the events of 2001. While earlier community officers were seen almost as social workers, the new officer is clearly a visible force in the streets. He engages in criminal investigations, order maintenance and law enforcement. Once again he serves as the traditional strong arm of the government. But he is more than that. He participates actively in citizen networks and cooperates with professional agencies such as schools and municipalities as well. He is a generalist who performs all policing tasks, except the ones that require specialist expertise. When such expertise is called in or new initiatives are introduced by the local government, the community officer provides valuable information and supports them.

The push towards a more assertive and firm enforcement led to a stronger involvement of community officers in crime fighting and in 'hard policing'. To close the gap between COP and crime investigation, PIE emphasizes a hybrid approach of COP in which the focus is on hard policing as well. But the community policeman or woman is also a professional whose knowledge and expertise has to be taken seriously by local administrative authorities. In this way, PIE also lay the foundation for enhancements of the professional competence of community officers.

\section{The current state of affairs: Dutch COP in practice}

According to Straver et al. (2009) the Dutch police are reasonably well integrated in neighborhoods, professional networks and local government. Such local integration also contributes to generally satisfactory levels of police legitimacy. From this perspective, the basic goals of COP appear to have been met rather well. However, an examination of recent literature published on this topic demonstrates that the overall picture is less straightforward. While the results are generally satisfactory, Dutch COP clearly faces a number of key challenges. We will discuss some of the discrepancies between the ambitions and achievements of the Dutch practice of COP In the following section (Stol, 2004, 2010; Terpstra, 2008, 2010; van der Torre, 2008; van der Torre et al, 2009; Bervoets et al., 2008, Bron et al., 2010; Straver et al., 2009; Vlek and van der Torre, 2010).

COP as the leading principle

Although COP is the guiding principle used in the day-to-day police work of all the 25 Dutch regional police forces, there are major differences between and even within 
the forces with regard to the organization and practice of COP. Some of the differences are greater than what would be expected purely from the perspective that local police units need the freedom to establish tailor-made solutions. For example, while in most forces, community officers are part of the basic unit, in others, they operate as rather isolated individuals or as part of a neighbourhood team. Another common difference is that in some forces, community officers only perform specific community policing tasks, whilst in others, their job includes criminal investigations and emergency assistance (Terpstra, 2008).

Further, each force has its own denomination for community officers and position in the hierarchical structure. There are also significant differences in the working styles of community officers across forces in different neighbourhoods (Terpstra, 2008;

Straver, et al., 2009).

\section{Balancing uniformity and variety}

This broad range of implementation styles has not gone unnoticed and the Dutch board of police chiefs now aims to end the proliferation of diverse styles. To this end, they have developed a national program for the development of area-bound policing. The board has opted for the further development of COP as the basic concept for the organization and practices of the whole police force and their vision is of relatively small-scale teams constituting the core of the organization and that support the community officers. Such a team is responsible for public safety and the integral exercise of the police function in its area. The board has rejected the idea of COP as a separate function that "complements" basic police services, crime investigation and other specialized services organized at the district level.

The national program now being rolled out contains a referential framework with nine facets or standards for the COP. These facets refer to the breadth of police services, the scale of the basic units, the position of the community officer, the management of community officers, the process-oriented practice, planning \& control, information, integral public safety, and leadership style (van Os, 2010). These nine facets are also seen as interrelated and depending on how they are implemented, can strengthen or weaken COP. Each year, audits are conducted to determine the degree to which police forces meet the criteria established and the board of police chiefs regularly discuss the results (van Os, 2010).

This strategy fits the ambition of the chiefs of police, which is to unify the Dutch police into one concern and to enhance professional competence through the implementation of national standards for specific policing domains. This aim is backed up by a number of educational programmes provided by the Dutch Police Academy (Vlek \& van der Torre, 2010). In addition, all forces appear to be increasing their number of community officers with financial support from the Minister of Internal Affairs and the Ministry of Kingdom Relations. The overall aim is to have one community officer per 5000 inhabitants. However, to date, no police force has yet been able achieve this or fully comply with stipulations related to the the nine COP facets outlined above.

\section{Changing image of Dutch COP}

Over the years, the image of COP have changed substantially. Community officers are now seen more as police officers and not as social workers. They contribute to law and crime investigation by taking on criminal investigations, enforcement, emergency services as well as by working on prevention and problem solving. 
Intelligence led policing has also become a big part of the community officers' duties. According to 'Police in Evolution' community officers not only have to act as sources of information for criminal investigations, they have an important 'signal and advice' function in that they are responsible for providing administrative authorities with information and early warnings about significant societal trends, emerging problems, signs of terrorism and radicalization.

\section{Role conflicts}

In his empirical study on policing on the streets Stol (2004) observed that community officers perform not only soft policing tasks, they take more repressive actions as well. They frequently deal with social disorder caused by youth, road safety issues and petty crime. Terpstra similarly observed in 2008 that rule enforcement has become an important part of their work. As a result, Stol says, their soft image no longer fits the way they actually do their job

The new role of community officers in intelligence led policing sometimes comes into conflict with their mandate to solve problems by cooperating with representatives of the community (Bervoets et al., 2009). Their role as law enforcers means that they are obliged to pass privileged and sensitive information to other police departments for purposes often outside of why it was provided to them (Kool, 2009). Community officers often report that this dual role harms the relations they have developed in their neighbourhoods as it muddies trust. Sometimes community officers also experience difficulties with the new repressive demands that are made upon them, for example, writing tickets in order to meet arbitrary performance targets.

Finding the balance between community policing and crime investigations

As outlined above, a long standing problem faced by Dutch police is that of balancing community policing, emergency responses and criminal investigations.

According to 'A Changing Police', all members of a community policing team cover the whole spectrum of police work. However, in practice, criminal investigation tend to be neglected by neighborhood teams because of a lack of necessary expertise and competences. Community officers are sometimes unable to feed detectives with knowledge of local perpetrators.

As crime control was once again designated a core task of police work in the 1990s, new specializations appeared and old specializations like that of the juvenile cop and the vice squad were reinstated in order to increase the level of professional competence in crime control. However, modernizing the process of criminal investigation alone was not sufficient. Many criminal cases $(160,000$ by some estimates) were not pursued by the police and eventually shelved, even though case screenings demonstrated sufficient indications for a follow up. Community officers thus had to participate in criminal investigations in one way or another, in order to fill this void.

The quest for a sensible balance between both disciplines has gone on for years, and a number of means of balancing the two have been taken years with experiment, including co-locating different units in the same building, functionally integrating detectives in neighborhood teams and having community officers work temporarily in investigative units (Zoomer, 2006).

Special crime investigation units have also been created in most police districts in order to improve the current level of collaboration and exchange of information 
between specialists and community officers, as well as to deal with all kinds of petty crime. This approach better integrates criminal investigations with community policing. However, there are some specific demarcations between the roles of the community officer and specialists. As a rule, neighborhood teams only deal with criminal offenses that don't require imprisonment (so called 'six hour cases'), however, community officers also serve as experts in community affairs during criminal investigations. Despite these initiatives, it remains that only a disappointing 12 percent of the community officer's time is spent on criminal investigations. This is far less than would be expected given the current "crisis" in crime investigations (van Os and Gooren, 2010).

Finding the balance between community policing and emergency response According to 'A Changing Police', emergency responses should be integrated into the work of community officers. However, this has proven to be less than feasible because community officers do not typically spend as much time on the streets as would be required for them to effectively meet this role. Furthermore, emergency response is discipline in and of itself, and it is aimed at immediate problem solving. It requires a different disposition than that required to deal with structural problems in the community.

Following from the original concept of community policing, the work of the community officer in the neighborhood would take the front seat. Because of their key role community officers can call upon other officers for emergency responses as well as for support and backup during criminal investigations. However, in practice community officers lack the necessary power and authority to play such a role well (van der Torre, 2007). What's more, police managers tend to see emergency responses as being more critical for gaining the trust of the public than community policing, and so tend to prioritize it accordingly.

Emergency response is thus organized in separate units, outside of neighborhood teams, and is directed out of a central (integrated) control room. A dispatcher prioritizes the requests for assistance from the public and he directs available surveillance cars accordingly. Priorities are based on written policy and requests that are less critical are left to the neighborhood teams so as to regulate public demand for police assistance. In practice, assistance calls are rarely passed on directly to community officers in the streets (van Os and Gooren, 2010). Instead, the community officer is involved as a way of filling up the gaps in the duty rosters of the emergency response teams.

Time spent in the neighborhood

Another area in which the COP has fallen slightly short of its ambitions is in the area of time spent on community policing. The intentions outlined in the COP's original framework state that community officers should spend about $80 \%$ of their time on community policing. However, Bron et al. (2010) observes that community officers spend only about $65 \%$ of their work hours on neighborhood related activities. The major part of their non- neighborhood related actions (32\%) consists of emergency response, surveillance and order maintenance that they do outside of their designated neighborhood as well as administrative tasks like maintaining contact through email, or writing a weblog to keep in contact with their neighborhood. About $3 \%$ of the remaining time is spent on attending briefings. 
The autonomy of the professional community officer was an important element in the original conception of community policing. Community oriented policing and problem solving (COPPS) demanded a non-bureaucratic way of management and it was thought that the traditional hierarchy and structure of responsibility had to be turned around (van Sluis, 2002) for this purpose.

Despite these noble intentions, the practice of granting professional autonomy to community officers is not particularly popular amongst researchers studying community policing. Writers in this area find that such an approach has resulted in officers having too much elbowroom to do things their own way. Internal instructions lack precision as a result of such autonomy and this creates a number of significant shortcomings (for example Bervoets et al., 2008; van der Torre, 2007).

While the researchers draw on studies of the behavior of community officers in coming to this conclusion, the officers themselves vehemently disagree. Officers themselves report that they often feel overruled by their managers in setting their priorities and executing their roles. This prevents them from spending more time on tasks they see as critical to the security of their neighborhoods (Bron et al, 2010).

The impact of the traditional police culture

The preoccupation with the management of COP has its roots in the perceived lack of professional competence of community officers. Despite its 30 year history, community policing as a profession can still be said to be in its infancy relative to the culture of the more established, or more traditional police force. "Street cop" culture is still dominant and community officers remain reactive and incident-focused. Systematic problem solving is not a common practice, even though it is said to be an indispensable tool for community policing (van Sluis, 2002). Terpstra ( $2010, .$. states that: ' Community policing is, despite its ambitions, largely reactive and ad hoc. The analyses of local problems of crime and disorder made by community officers are often rather unsystematic and lack explicitness. To a large degree they are based on quite tacit, practical knowledge'.

Part of the explanation for this is that community officers tend to favour direct immediate action and rely more on information they receive from personal contacts with citizens ('street knowledge') than on information gained by research and science. Their own information and personal experience in the police practice are seen as superior to knowledge from central databases. Their actions are thus primarily practice based, not evidence based (Terpstra, 2008). This tendency is furthered by the fact that community officers tend to distrust standardized instruments that are developed by their colleagues in the police force, including the rather successful Crime and Disturbance Area Scan that is currently being implemented.

To address this problem, the Dutch Police Academy has recently developed a standard program to educate community officers. Before, each police force had its own course at the Police Academy, but the newly developed program aims to integrate training across police forces and deliver community officers at two levels, the highest being that of inspectors with bachelor's degrees.

\section{Cooperation with other agencies, although with little attention being paid to citizen participation}

Another feature of current Dutch COP is the cooperation between agencies involved in local security. Much of this cooperation is initiated by the community officers themselves. Although they do well with other agencies, community officers have greater difficulties supporting or even appreciating undertaken by citizens. The role of 
citizens appears to be limited in their view to that initiatives of providers of information (the eyes and ears of the police) (Terpstra, 2008). Despite all efforts to comply with the 'official' police policy that considers safety a joint effort between the police and the citizens, community officers are still rather 'police centred' in their orientation, (van Os, 2010).

\section{Integration into the local community?}

Integration into the local community is one of the central ambitions of Dutch COP, but its importance seems to be slowly eroding. Police forces have tried to bring more 'blue' back by increasing area bound policing, despite the fact that many cities have installed enforcers of their own. These are non-police personnel with limited responsibilities and tasks, but who are controlled exclusively by the local government. This trend was furthered by the retreat of the police to their core tasks and by a tremendous growth in the use of local administrative sanctions for nuisances and minor offences (Van der Vijver, 2004; Sackers, 2010). This rather chaotic proliferation of guards, watchmen, wardens, stewards and others (the 'extended policing family') has led to increasing debate in the Netherlands about reinstating a kind of local police.

A recent survey among members of local councils showed that a majority (55\%) were in favor of the return of a local police force, despite their overall satisfaction with the work of the regional police forces (van der Torre et al. 2009). Part of the reason for this is that councilors are pessimistic about their influence on police policies under the current structure. They fear that an increase in central or national steering of the police will be detrimental for the local determination of police work. A local police force could both strengthen the local influence onn policing as well as put a stop to the chaotic proliferation of non-police enforcement and surveillance.

\section{Analysis: shifts explained}

What factors explain the shifts that Dutch COP has undergone? The following are key factors that have been identified as impacting the face of the Dutch COP over various phases of its existence.

The Dutch aversion towards centralized state power

The Dutch attitude towards the police and the power of the state has always been ambiguous. This ambiguity is reflected in the state structure (the Netherlands are a decentralized unitary state), in which there is no room for a strong, centrally managed, police apparatus. Aversion to a strong, centralized police apparatus was initially fueled by the French domination of the state and local police forces a long time ago, as well as German occupation during the Second World War. The current decentralized police system reflects the broadly shared view that the police should be oriented primarily towards delivering services to the public and should serve as the strong arm of central government to a lesser degree. It was this view that made the Netherlands fertile ground for COP in the first place, although the shape of the COP has changed constantly since its inception.

\section{The impact of managerialism}

In its current form, Dutch COP appears to have been stripped of the more radical elements inherent in its original framework. For example, there was the initial 
requirement to overturn the traditional police organization and to empower rank-andfile officers in the development of strategic police policy.

This 'revolutionary' potential of COP was successfully neutralized by an increase in the level of top-down steering. Police managers are now again more inclined to see rank-and-file officers merely as implementers of policies formulated by the top that are controlled by the use of standard operation procedures and statistical analysis such as that are available through Compstat Management. This has undoubtedly led to less professional autonomy for community officers (Van Os 2010, 267), but part of the reason for this rise despite the noble intentions for COP was the community officer's poor performance in the fight against crime.

Above all, this shift meant a comeback of the professional model of policing that was dominant in the 1960s and early 1970s, and a further inhibition of the development of post-bureaucratic ways of organizing.

\section{Changes in the political and social climate}

The growing popularity of the reform model amongst Dutch policy makers and police managers reflects not only a shift in COP practice but also a major shift in Dutch safety policy of the last fifteen years. The shift has been primarily towards a harsher, stricter policy with extensive use of penal sanctions (Das et al., 2002; Terpstra and van der Vijver, 2006). Such a penal rationale has permeated virtually all measures of crime prevention and prevention now means only proactive intervention on the basis of risk profiles. The focus is primarily on street crime (van Swaaningen, 2005, 303).

\section{Moving to and fro between hard and soft policing}

A regression toward hard-line enforcement (Punch, 2010, 201) threatens the very survival of the COP. But the pressures to reform were real and insistent. The 1990s saw strong pressures exerted on the police to be more effective in the fight against crime, and to focus less on delivering services to the public. It has also led to the emergence of alternatives to the COP model, including the zero tolerance movement. As a result, the police became more visible on the streets and were more assertive, and there were clear signs of a new élan amongst police officers (Punch, 2006).

\section{The impact of police system reforms}

Since the Police Act of 1993 came into force, regional police forces have become larger and more complex organisations. The reorganization of 1993 was inspired by the larger discontent with police performance and caused a fundamental break with the COP philosophy. It thus heralded a partial return to the professional model of policing which is based on larger, centralized police forces and greater distance between the police and the public. In retrospect however, this shift can be said to have been a temporary one. COP was soon reintroduced in the form of area-bound policing and this served to balance somewhat against the growing detachment and centralization (Cachet et al., 1998).

\section{Innovation dynamics within the police}

Innovations in Dutch policing often have a high turnover rate (Hoogenboom, 2006). New ideas and concepts alternate quickly, whereas real shifts in the way police officers think and act takes much more time to enact and the many new models initiated by management have not changed the community officers' day-to-day activities significantly (Terpstra 2010, 228). For example, some elements of the zero- 
tolerance or reassurance policing have crept into their day-to-day activities but this has been a very slow development in the work of the community officers. COP has remained the guiding principle over the years, even though it too had a slow start and has changed over the years. There has been an almost invisible incorporation of other concepts that continue to come and go in a complex process of change (compare Pollitt and Bouckaert, 2009).

\section{Unifying tendencies within the Dutch police}

The term 'community policing' has suffered as a result of its abstract conceptualization as this has hampered the development of a shared interpretation and implementation. However, in recent years, the further development of COP has been made part of a systematic program run by the Board of Chiefs of Police and this has been backed up by the educational program introduced by the Dutch Police Academy. These efforts are further supported by a national referential framework for COP.

\section{The future prospects of Dutch COP}

Any assertion one could make about the future of Dutch COP would be speculative in nature. Nevertheless, certain trends can be extrapolated and several key threats and challenges can be identified. Many of these challenges are far from new, such as the continuing need to involve citizens more actively into COP, the need to balance COP with emergency response and crime control priorities, and the need to reconcile the many claims that are made upon community officers. The board of police chiefs has now formulated a vision of policing which more clearly guides the process of COP implementation.

A new challenge likely to come up in the near future is that of serious budget cuts. Such cuts have already been announced and are likely to add significant obstacles to the development of COP.

\section{A strategy for the diffusion and adoption of COP}

National standards for the organization and execution of community policing have been set in place, as have educational foundations. These illustrate the growing unity of the Dutch police. However, although significant progress has been made, community policing is still not fully developed as a profession.

Nonetheless, the referential frame for COP and the support given to it by the program manager are invaluable to the serious practitioner. With these in place, there is less risk of COP remaining an abstract concept, and being interpreted in different ways across and within police forces. However, while uniformity and compliance with protocol are important, they are not targets in themselves. These goals have to be weighed against the need for solutions that are more closely targeted to the needs of the local community.

While the referential frame for COP is invaluable, it is best regarded as a seed for planting than as a plant for potting. Specifically, it is the view of these authors that It should not function as a mere blueprint. Rather, it needs to be adopted in a way that facilitates learning and the establishment of policing best practices. This address the current problem of poor adherence to practices that have proven their value in other police forces.

A positive side effect will be that the sometimes heavily debated concept of 'professional autonomy' will be guided by professional norms and standards instead 
of individual discretion (Van Os, 2010). This process would be analogous to the development of the criminal investigations process that has gone on in the Netherlands. While there is always room for solutions that are tailor made based on the information and experience of community officers, these are best created under a framework where deviations from evidence-base practices have to be clearly articulated and justified. It may take up to ten years for this development to be fully implemented. If seriously adopted, this may just be the latest development and most important development in the constant quest to pursue professional excellence while balancing the focus on local communities.

\section{Increasing quality and professionalism}

An easy way to increase the quality and professionalism would be to increase the number of community officers on the ground. While increasing the number of community officers may do wonders for the effectiveness of the COP, numbers alone may not significantly increase the amount of time devoted to neighborhood related activities. This would require serious parallel efforts in improving the manpower situation in other parts of the police force, implementing adequate administrative support for area bound policing efforts and increasing the level of professionalism among community officers.

A second way to improve professionalism and quality is to reintroduce a focus on problem oriented policing (POP). This model seems to have fallen behind and it would be good for it to catch up. The ideal scenario is for POP to become an integral part of the repertoire of the professional community officer. However, this may be too optimistic a goal (compare Braga and Weisburd, 2006). It would be good at least to increase the problem solving skills of community officers as this would position the community officer more firmly within the broader safety program of the local government.

The necessary tools like the Crime and Disturbance Area Scan are already there. However, in addition two shifts seem to be required: first, a shift from a primarily practice-based work style towards a primarily evidence-based one, and second, a shift from a police centered approach towards one in which the police play primarily a supportive role and act as the last resort (Straten, van Sluis, Thaens and Bekkers, 2010).

Two other changes that would be necessary to make is that of increasing the participation of citizens and improving the professional skills of the community officer in the area of crime investigation. These will be even more indispensable for successful community policing in the future than they are at present (see Tops et al. 2010).

In part, these changes require that the Dutch police return to the inspiration behind ' $A$ Changing Police' and its original plea for greater use of the knowledge, creativity and problem solving capacity of rank-and file-officers whose core business is professional problem solving, and to ensure co-operation with a variety of internal and external strategic partners.

But for such a strategy to work, it would require leadership styles and management performance systems that recognize and reward problem oriented policing.

\section{'Information led cops'}

More than in the past, community officers have to have a clear image of the concrete results they want to achieve and to perform their job accordingly. This is necessary if they wish to avoid unrealistic expectations and demands from their partners and the 
public. To this end, detailed information about what is going on in communities is crucial. This is especially so in efforts to fight radicalization and terrorism. Community officers are the first link in the safety chain because they have ample access to community intelligence and it is through them that COP can effectively be combined with hard policing.

Fine tuning police strategies

Given the multiple demands on the police, to be effective, in the future COP has to better integrate the multiple policing models and strategies such as reassurance policing, 'fixing broken windows' policing and POP. COP needs also to be better tuned to other seemingly incomparable popular models such as Compstat so that the two complement rather than oppose each other's effects (see for example Willis et al., 2010).

\section{COP in a centralized Dutch police system}

As outlined above, the Dutch police have been subject to more and more direct political control by the Minister of the Interior and Kingdom Relations. Recently, the trend toward an even more centrally and nationally organized police force has become unmistakable. The Rutte cabinet that came into power in October 2010 has made the unambiguous choice to have for a single, unified national police force that is spread across a consolidated number of regions (10 versus the existing 25). In a more centralized system of policing, the balance between central national and regional tasks will be much harder to maintain.

The question that arises then is whether Dutch COP will be resilient enough to counter the strong centralization tendencies and if there will be enough room within its bounds to safeguard the provision of tailor-made local policing.

\section{Conclusions}

Despite great changes in Dutch society and the many policing innovations that have come and gone, COP has continued to be a key feature of Dutch policing for the last three decades. The police and police authorities have had to strike a the balance between the different demands of state, community and profession and COP had had to mould and remould itself accordingly. Among other things, the Dutch COP had had to come to grips with policing models that at various times, are either more oriented toward the state, or to the police as a profession. Needless to say, the organization and implementation of Dutch COP has not been without obstacle, and it continues to be a 'work in progress'.

Despite these constant assaults, Dutch COP has proven itself to be the most enduring and integrative platform that has managed to successfully survive the many changes in the public and professional view of police work.

\section{References}

Bervoets, E. et al. (2009) Bij de tijd: wijkagenten in Hollands Midden. Beschrijving en analyse van dagelijkse praktijken. COT, Boom Juridische Uitgevers, den Haag

Braga, A. and D. Weisburd (2006) 'Problem-oriented policing: The disconnect between principle and practice'. In: Weisburd, D. en Anthony A. Braga (2006), Police Innovation; Contrasting Perspectives. Cambridge University Press, New York.

Brogden, M. and P. Nijhar (2005) Community Policing. National and international models and approaches, Willan, Cullompton 
Beumer, R.J. (1997) Gebiedsgebonden politiewerk: een verkenning, Den Haag: Ministerie van BZK

Cachet, A., E.J. van der Torre and W. van Natijne (1998) De blijvende betekenis van Politie in Verandering, Den Haag: Elsevier

Das, Dilip, Leo Huberts and Ronald van Steden (2002) 'The changing "soul" of Dutch Policing. Responses to new security demands and the relationship with Dutch tradition'. Policing: An International Journal of Police Strategies \& Management, Vol. 30 No. 3, 2007, pp. 518-532

De Kimpe, Sofie and Lex Cachet (2008) 'Police and local safety policy'. In: Lex Cachet et. al (eds.) Governance of Security in The Netherlands and Belgium, pp.209-234. Boom Legal Publishers, The Hague

Hoogenboom, A.B. (2009). 'Dingen veranderen en blijven gelijk'. Justitiële verkenningen 35(1), 63-77.

Kool, Wouter de (2007) 'Mission Impossible?: Het signaleren van islamitisch radicalisme en terrorisme door Nederlandse wijkagenten'. In: Het Tijdschrift voor de Politie, 2007, jrg. 69 , nr. 3, p. 4-8

Pollitt, Christopher and Geert Bouckaert (2009) Continuity and Change in Public Policy and Management. Edward Elgar, Cheltenham

Projectgroep Organisatie Structuren (1977) Politie in Verandering: een voorlopig theoretisch model. Staatsuitgeverij, Den Haag.

Projectgroep Visie op de Politiefunctie (2005): Politie in ontwikkeling; visie op de politiefunctie. Den Haag: NPI

Punch, M. et al. (2002) 'Dutch "COP". Developing community policing in the Netherlands'. Policing: An International Journal of Police Strategies \& Management, Vol. 25, No. 1 pp. 66-79

Punch, M. (2006). Van 'alles mag' naar 'zero tolerance': policy transfer en de Nederlandse politie. Apeldoorn: P\&W Verkenningen

Punch, M. et al. (2008). Community Policing in the Netherlands: Four generations of Redefinition. T. Williamson (ed.) The Handbook of Knowledge Based Policing: Current Conceptions and Future Directions

Punch, M. (2010) 'COP's vulnerability to paradigm swing'. In: Cahiers Politiestudies, Jaargang 103, nr. 16, p. 199-214

Stol, W.Ph., et al. (2004) Politiestraatwerk in Nederland. Noodhulp en gebiedswerk: inhoud, samenhang, verandering en sturing. Politie en Wetenschap nr. 14

Stol, W.Ph. (2009) 'Veranderingen in politiestraatwerk in Nederland: 1991-2005'. Cahiers Politiestudies, Jaargang 2009-4, nr. 13, p. 199-227

Straten, G.J. A. van Sluis, M. Thaens and V. Bekkers (2010) Informatiegestuurde politiemensen. Erasmus Universiteit, Politie en Wetenschap

Straver, Ries et. Al (2009), Ries Straver et al. Integratie van Nederlandse politie in wijken, netwerken en lokaal bestuur. Dordrecht: Stichting SMVP Producties.

Terpstra, J. and C.D. van der Vijver (2006) 'The police, changing security arrangements and late modernity: the case of The Netherlands'. German Policy Studies 3(1): 80-111 
Terpstra, J. (2008) Wijkagenten en hun dagelijks werk. Politie en Wetenschap, nr. 46

Terpstra, J. (2010) 'Community Policing in the Netherlands and the use of other related police models: problem-oriented, disorder and reassuring policing'. Cahiers Politiestudies, Jaargang 10-3, nr. 16, p. 215-232

Tops. P., van Duin, M., van Os, P. Zourides, S., Sleuren of Sturen, Gemeenten en de sturing van veiligheid en politie (2010) .

Torre, E.J. (1999) Politiewerk: Politiestijlen, Community Policing, Professionalisme Politiewerk. Samson,

Torre, E.J. van der (2007) Lokale politiechefs. Het middenkader in de basispolitiezorg. Politie en Wetenschap 38, Elsevier Overheid, Den Haag (typologie van wijkteamchefs en van operationele chefs)

van der Vijver, C.D. (2004), 'Kerntaken, sturing en professionaliteit'. Stokkum, B. van and Gunther Moor, L. (eds) (2004), Onoprechte handhaving? Prestatiecontracten, beleidsvrijheid en politie-ethiek. Dordrecht: Stichting Maatschappij, Veiligheid en Politie

van Os, P. (2010) 'Community-oriented Policing in the Netherlands: a process with many obstacles'. In: Cahiers Politiestudies, Jaargang 10-3, nr. 16, p. 261-268

van Os, P. and W. Gooren(2010) Operationalisering referentiekader gebiedsgebonden politie; de tweede oogst. (to be published)

van Sluis, A. (2002) Van 'planning and control' naar strategische beleidsvorming. Een onderzoek naar beleidsvorming bij de politie. Doctoral Thesis, Erasmus University Rotterdam

van Sluis, A. et al. (2008) 'Results-based agreements for the police in The Netherlands'. Policing: An International Journal of Police Strategies \& Management, Vol. 31, No. 3 pp. 415-439

van Swaaningen, Rene (2005) 'Public safety and the management of fear'. Theoretical Criminology, Vol. 9(3): 289-305

Vlek, F. and E.J. van der Torre (2010) 'De Nederlandse politie sinds 1993: een wereld van verschil. Beelden over en uit de praktijk'. Cahiers Politiestudies, Jaargang 2009-4, no. 13 , p. $229-286$

Willis, James J. et al. (2010) 'Recommendations for Integrating Compstat and Community Policing. Policing: An International Journal of Police Strategies and Management (2007) 30:237-256

Zoomer, O. (2006) De opsporingsfunctie binnen de gebiedsgebonden politiezorg. Zeist, Kerckebosch

\section{About the authors}

Dr. A. van Sluis and Dr. P.K. Marks are Assistant Professor, Dr. A. Cachet is Associate Professor and R. Prins Msc is Phd student at the Faculty of Social Sciences of the Erasmus University Rotterdam. Commissioner Peter van Os is Program Manager Development Community Oriented Policing for the Dutch Board of Chiefs of Police 